\title{
C-reactive protein, cardiovascular risk factors and the association with myocardial infarction in men
}

\author{
C. J. M. DOGGEN', R. J. BERCKMANS', A. STURK', V. MANGER CATS' \& F. R. ROSENDAAL ${ }^{++}$ \\ From the 'Department of Clincal Eptdemiologys. Department of Clinual Chenustry. 'Department of Cardiology. and 'Hemostasis and Thrombosts \\ Research Center. Leiden Unuversity Meducal Center. Letden. the Netherlands
}

\begin{abstract}
Doggen CJM, Berckmans RJ. Sturk A, Manger Cats V, Rosendaal FR (Leiden University Medical Center, the Netherlands). C-reactive protein. cardiovascular risk factors and the association with myocardial infarction in men. Jntern Med 2000; 248: $406-414$.
\end{abstract}

Objectives. This study had three objectives: first. to investigate the association of C-reactive protein levels and myocardial infarction amongst men; secondly, to study the associations of C-reactive protein levels with cardiovascular risk factors; and thirdly, to adjust the risk of myocardial infarction for such factors.

Design and subjects. A case-control study including 560 patients with a first myocardial infarction who had survived at least 6 months. plus 646 control subjects.

Results. Patients had significantly higher levels of $\mathrm{C}$ reactive protein (mean $2.2 \mathrm{mg} \mathrm{L}^{-1}$ ) than control subjects (mean $1.7 \mathrm{mg} \mathrm{L}^{-1} ; P<0.001$ ). Persons in the highest quintile of $\mathrm{C}$-reactive protein had an unadjusted 1.9-fold increased risk of myocardial infarction compared with persons in the lowest quintile (odds ratio $1.9 .95 \% \mathrm{CI}$ : 1.3-2.7). C-reactive protein was, in addition to smoking, associated with several cardiovascular risk factors: age, obesity. diabetes, blood pressure, triglycerides and in associated to HDL cholesterol. Adjustment fo these variables, especially for total cholesterol, HDL cholesterol and triglycerides, substantially decreased the risk of myocardial infarction for persons in the highest quintile of C-reactive protein, compared to those in the lowest quintile. to 1.3 (95\% CI: 0.9-1.9). Conclusions. Our findings confirm previous reports that $\mathrm{C}$-reactive protein predicts the risk of myocardial infarction. However, this association does not appear to be causal, since the increase in risk can to a large extent be explained by the presence of other cardiovascular risk factors.

Keywords: C-reactive protein, inflammation marker, myocardial infarction. risk factors.

\section{Introduction}

The chronic process of atherosclerosis and the acute process of thrombosis are both involved in the development of a myocardial infarction [1]. Atherosclerosis is increasingly thought to be an inflammatory disease and inflammatory cells may account for the local weakening of the atherosclerotic plaque that results in its rupture, with the consequential formation of a thrombus and occlusion of the artery $[2,3]$. It is possible that inflammation not only contributes to the progression of atherosclerosis but might also play a role in the activation of clotting factors. C-reactive protein, a sensitive marker of inflammatory activity, induces monocytes to express tissue factor, the initiator of the extrinsic pathway of coagulation [4]. Thus, inflammation may influence the chronic as well as the acute process [1; $;$ ].

$C$-reactive protein is an acute phase protein and its production by the liver is stimulated by cytokines, such as interleukin-6. Its plasma level is increased up to several hundred-fold during acute inflammation [6]. It has been suggested that this protein is a risk factor for recurrent events in patients with angina pectoris and in patients with unstable coronary artery disease [7-10]. The risk of elevated C-reactive protein levels for a first myocardial infarction has been investigated in several nested 
case-control studies with conflicting results [1113]. C-reactive protein is an acute-phase reactant that may rise in response to many stimuli. Therefore, associations with cardiovascular risk factors or subclinical disease are likely explanations for the observed associations of C-reactive protein and risk. In the 'Study of Myocardial Infarctions Leiden (SMILE)', we investigated $C$-reactive protein levels in 560 men with a nonfatal myocardial infarction and 646 control subjects from the Netherlands, and calculated risks of myocardial infarction with increasing quintile of C-reactive protein level. We extensively assessed the relationship of C-reactive protein levels with other márkers of risk and adjusted the risk of myocardial infarction for cardiovascular risk factors that were found to be associated with C-reactive protein levels.

\section{Materials and methods}

Details of the 'Study of Myocardial Infarctions Leiden' have been described elsewhere [14]. Briefly. patients were men below the age of 70 years, with a first myocardial infarction that had occurred between January 1990 and January 1996. The control group also consisted of men, frequency matched on age to the patients, who had undergone an orthopaedic intervention between January 1990 and May 1996 and had received prophylactic anticoagulants for a short period after the intervention. Both patients and control subjects were born in the Netherlands. They completed a questionnaire on smoking habits, alcohol use and the presence of diabetes. Smoking was defined as never, former or current. Blood pressure was measured after a rest of at least $10 \mathrm{~min}$ with the person sitting in an upright position. The body mass index was derived by dividing weight (kilograms) by squared height (metres), and obesity was defined at an index of $30 \mathrm{~kg} \mathrm{~m}^{-2}$ or above.

Fasting blood samples were drawn from the antecubital vein in Sarstedt Monovette tubes and obtained between July 1994 and February 1997. Blood in the first tube was allowed to clot and the serum was used for measuring total cholesterol. HDL cholesterol and triglyceride levels. Blood taken in $0.109 \mathrm{~mol} \mathrm{~L}^{-1}$ trisodium citrate was centrifuged for $10 \mathrm{~min}$ at $3000 \mathrm{~g}$ at room temperature. The citrated plasma was aliquoted in multiple tubes and immediately stored at $-80^{\circ} \mathrm{C}$. Total cholesterol and triglyceride concentrations were measured using enzymatic assays adapted to a Hitachi 747 (Boehringer Mannheim). High density lipoprotein (HDL) cholesterol concentration was measured on a Hitachi 911 (Boehringer Mannheim). C-reactive protein levels were measured using an enzyme linked immunosorbent assay (CRP EIA HS assay; Kordia, the Netherlands). The within-day, between microplate coefficient of variation was $5.2 \%$ at $0.82 \mathrm{mg} \mathrm{L}^{-1}$ and $6.8 \%$ at $8.9 \mathrm{mg} \mathrm{L}^{-1}(n=16)$. The between-day coefficient of variation was $5.3 \%$ and $5.1 \%$ at the same respective concentrations $(n=10)$.

The mean age of patients and control subjects at the time of blood sampling was 59.1 (SE 0.4) and 57.3 (SE 0.4) years, respectively. The median time between myocardial infarction, orthopaedic intervention and blood collection was, respectively. 2.6 years and 2.9 years, with a minimum of 6 months. The closer the proximity of the event to the time of blood collection, the higher the $C$ reactive protein levels in the Cardiovascular Health Study [12]. To evaluate whether C-reactive protein levels decreased after myocardial infarction in our study, we stratified the elapsed time since myocardial infarction into 1-year categories. The elapsed time since myocardial infarction did not relate to $\mathrm{C}$ reactive protein levels (Table 1 ).

As C-reactive protein levels were skewed, 10logtransformation was applied. These log-transformed values were used in the analyses and differences between the log-transformed values were tested by means of analysis of variance (ANOVA). However, all values presented are converted back to geometric means with the appropriate $95 \%$ confidence interval (CI). $P$-values were considered significant at a value $<0.05$. Quintiles of $C$-reactive protein were defined on the basis of the distribution of $\mathrm{C}$-reactive protein levels amongst control subjects. The lowest quintile was used as a reference category for calculating odds ratios (OR). Logistic regression was used to adjust for age, smoking and other cardiovascular risk factors. Confidence intervals of $95 \%(95 \% \mathrm{CI})$ for odds ratios were calculated by the method of Woolf [15] or based on the standard errors from the logistic model. A linear test for trend [16] was used to assess any relationship between increasing quintiles of $\mathrm{C}$ reactive protein levels and the risk of myocardial infarction. Quintiles of total cholesterol, HDL cho- 
lesterol and triglyceride levels were defined on the basis of the distribution amongst control subjects. However, in the logistic regression model the three lipid factors were included as continuous variables, as were systolic and diastolic blood pressure.

\section{Results \\ C-reactive protein level in patients with myocardial infarction and control subjects}

The mean C-reactive protein level amongst patıents with a myocardial infarction was $2.2 \mathrm{mg} \mathrm{L}^{-1}(\mathrm{Cr}$ : 2.0-2.4) and varied between $0.1 \mathrm{mg} \mathrm{L}^{-1}$ and $46.8 \mathrm{mg} \mathrm{L}^{-1}$. For control subjects the mean level was $1.7 \mathrm{mg} \mathrm{L}^{-1}$ (Cl: $\left.1.6-1.9\right)$, with a range between $0.03 \mathrm{mg} \mathrm{L}^{-1}$ and $115.1 \mathrm{mg} \mathrm{L}^{-1}$. Levels in patients were significantly higher compared with control subjects $(P<0.001)$. The difference was also evident in the absence of alcohol use, obesity or diabetes. but not in the absence of smoking (Table 2). C-reactive protein levels above $10 \mathrm{mg} \mathrm{L}^{-1}$, indicating the presence of organic disease [6], e.g. rheumatoid arthritis or colitis ulcerosa, were found in 38 patients and 55 control subjects. Exclusion of these persons reduced the mean $C$-reactive protein levels to $1.9 \mathrm{mg} \mathrm{L}^{-1}(\mathrm{Cl}$ : $1.8-2.1$ ) for patients and to $1.4 \mathrm{mg} \mathrm{L}^{-1}$ (CI: $1.3-$ 1.5) for control subjects $(P<0.001)$.

Association between C-reactive protein level and cardiovascular risk factors

As can be seen in Fig. 1, overall $C$-reactive protein levels increase gradually with age, with levels at 7075 years being almost twice those at 30-40 years. At all ages, except amongst the very oldest. $C$ reactive protein levels in patients were between 0.3 and $0.5 \mathrm{mg} \mathrm{L}^{-1}$ higher than in controls.

Smokers had higher C-reactive protein levels than never smokers, with former smokers having intermediate levels, in patients as well as in control subjects (both $P<0.001$; Table 2). Alcohol use was associated with $\mathrm{C}$-reactive protein levels in patients, with never users having higher levels compared with regular users. However, no difference in levels was found amongst control subjects. Obese persons had higher levels of C-reactive protein compared to men without this risk factor (all $P<0.05$; Table 3). Men with diabetes had higher levels compared to those without diabetes, although this was only significantly in patients.

Systolic and diastolic blood pressure were significantly associated with increased C-reactive protein levels in control subjects, but not in patients. The mean C-reactive protein level for 104 control subjects with a systolic blood pressure of $165 \mathrm{~mm} \mathrm{Hg}$ or above was $2.8 \mathrm{mg} \mathrm{L}^{-1}$ (CI: $2.3-$ 3.5), compared with $1.6 \mathrm{mg} \mathrm{L}^{-1}$ (CI: 1.4-1.7) for those with lower levels of systolic blood pressure $(P<0.001)$. The mean $C$-reactive protein level of 179 control subjects with diastolic blood pressure of $95 \mathrm{~mm} \mathrm{Hg}$ or above was $2.0 \mathrm{mg} \mathrm{L}^{-1}$ (CI: 1.7-2.4) vs. $1.6 \mathrm{mg} \mathrm{L}^{-1}$ (CI: 1.4-1.8) for those with fower blood pressure $(P<0.05)$.

The $C$-reactive protein level was not assoeilated with total cholesterol levels in patients, nor in control subjects (Table 3). However, low C-reactive protein levels were found in control subjects and patients in the highest quintile of HDL cholesterol. In contrast, high levels of $\mathrm{C}$-reactive protein were found in control subjects in the highest quintile of triglyceride levels. In patients, no consistent trend was found in C-reactive protein levels in association with triglyceride quintiles.

C-reactive protein level and risk of myocardial infarction, adjusted for cardiovascular risk factors

The distribution of patients and control subjects by quintiles of C-reactive protein levels is shown in Table 4 . The risk of myocardial infarction increased with increasing quintiles ( $P<0.001$ for trend). The unadjusted risk of myocardial infarction for men in the highest quintile, compared with those in the lowest quintile was 1.9-fold increased (OR 1.9. 95\% CI: $1.3-2.7$ ). A similar trend was found för men under the age of 50 years. Adjustment for age and smoking led to similar patterns in the risk of myocardial infarction: the highest risk was found for men in the highest quintile. Adjustment for age, total cholesterol. HDL cholesterol and triglycerides lowered the estimated odds ratios: the unadjusted odds ratio of 1.9 for the highest vs. the lowest quintile of C-reactive protein, decreased to 1.3 (OR 1.3. 95\% CI: 0.9-1.9). Further adjustment for smoking, alcohol use. obesity, diabetes and blood 


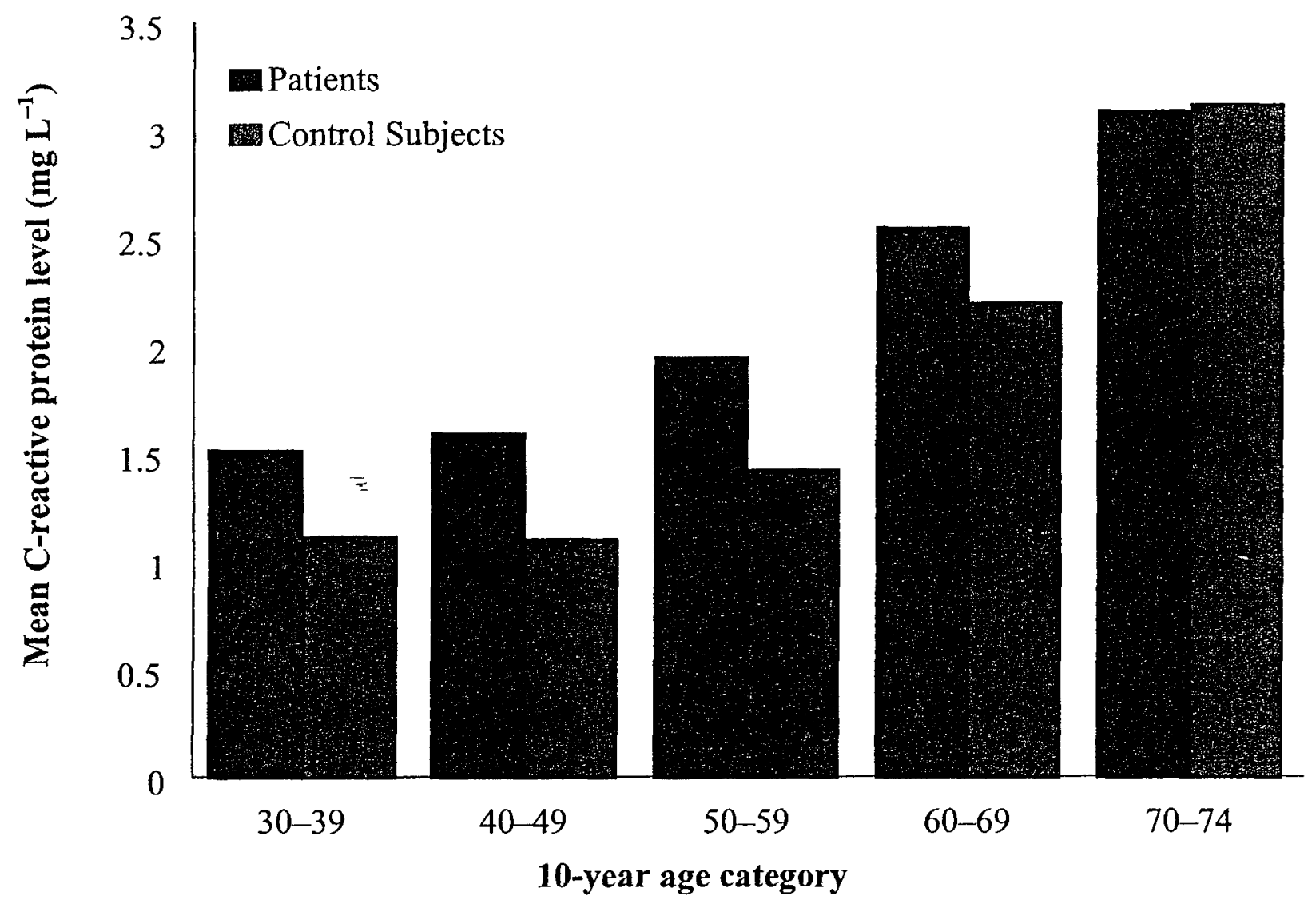

Fig. 1 C-reactive protein levels amongst patients with myocardial infarction and control subjects. by 10-year age categories.

\begin{tabular}{|c|c|c|c|c|c|c|}
\hline & & \multicolumn{5}{|c|}{ 10-year age categories } \\
\hline \multicolumn{2}{|c|}{$\mathcal{C}$-reactive protein level $\left(\mathrm{mg} \mathrm{L}^{-1}\right)$} & $30-39$ & $40-49$ & $50-59$ & $60-69$ & $70-74$ \\
\hline \multirow{2}{*}{ Patients } & $\mathrm{N}$ & 10 & 99 & 161 & 221 & 69 \\
\hline & Mean (CI) & $1.5(0.8-3.0)$ & $1.6(1.3-2.0\}$ & $2.0(1.7-2.3)$ & $2.6(22-3.0)$ & $31(2.5-3.9)$ \\
\hline \multirow[t]{3}{*}{ Control subjects } & $\mathrm{N}$ & 46 & 104 & 181 & 248 & 57 \\
\hline & Mean $(\mathrm{CI})$ & $1.1(0.7-1.7)$ & $1.1(0.9-1.4)$ & $1.4(1.2-1.7)$ & $2.2(1.9-2.6)$ & $3.1(2.3-4.3)$ \\
\hline & $\begin{array}{l}P \text {-value } \\
\text { ANOVA }\end{array}$ & 0.53 & 0.02 & 0.01 & 016 & 0.97 \\
\hline
\end{tabular}

Table 1 Elapsed time since myocardial infarction and $\mathrm{C}$-reactıve protein levels

\begin{tabular}{lll}
\hline $\begin{array}{l}\text { Number of years } \\
\text { since myocardial } \\
\text { infarction }\end{array}$ & $\begin{array}{l}\text { Number } \\
\text { of } \\
\text { patients }\end{array}$ & $\begin{array}{l}\text { C-reactive protein } \\
\text { level }\left(\mathrm{mg} \mathrm{L}^{-1}\right) \\
\text { mean }(\mathrm{CI})\end{array}$ \\
\hline $0.5-1$ & 33 & $1.6(1.2-2.3)$ \\
$1-2$ & 157 & $2.2(1.8-2.6)$ \\
$2-3$ & 121 & $2.2(1.8-2.7)$ \\
$3-4$ & 116 & $2.5(2.0-3.1)$ \\
$4-5$ & 113 & $2.2(1.8-2.6)$ \\
$5-6$ & 20 & $2.6(17-40)$ \\
\hline
\end{tabular}

$P$-value $A N O V A=0.46$ pressure, several of the cardiovascular risk factors identified as being associated with $\mathrm{C}$-reactive protein levels, did not alter these odds ratios.

To rule out the effect of outlying values we repeated these analyses for persons who had a Creactive protein level lower than $10 \mathrm{mg} \mathrm{L}^{-1}$. This gave an unadjusted risk of myocardial infarction for men in the highest quintile compared to those in the lowest quintile of 2.2 (OR $2.2,95 \%$ CI: $1.5-3.2$ ). Adjustments for age. total cholesterol. HDL cholesterol and triglycerides decreased this risk to 1.4 (OR 1.4. 95\% CI: $1.0-2.1$ ). without any increased risk 
Table 2 Difference in C-reactive protein levels between patients with myocardial infarction and control subjects and the association between $C$-reactive protein levels and cardiovascular risk factors in both groups

\begin{tabular}{|c|c|c|c|c|c|c|}
\hline \multirow{3}{*}{$\begin{array}{l}\text { Cardiovascular } \\
\text { risk factor }\end{array}$} & & \multicolumn{4}{|c|}{ C-reactive protein ( $\left.\mathrm{mg} \mathrm{L}^{-1}\right)$} & \\
\hline & & \multicolumn{2}{|l|}{ Patients } & \multicolumn{2}{|c|}{ Control subjects } & \multirow{2}{*}{$\begin{array}{l}\text { P-value of difference } \\
\text { patients and control } \\
\text { subjects }\end{array}$} \\
\hline & & Number & Mean $(\mathrm{CI})^{*} \dagger$ & Number & Mean $(\mathrm{CI})^{*}+\dot{\dagger}$ & \\
\hline \multirow{2}{*}{\multicolumn{2}{|c|}{$\begin{array}{l}\text { Overall } \\
\text { Smoking }\end{array}$}} & 560 & $2.2(2.0-2.4)$ & 646 & $1.7(1.6-1.9)$ & $<0.001$ \\
\hline & & & & & & " \\
\hline \multicolumn{2}{|l|}{ Never } & 44 & $1.3(0.9-1.8)$ & 117 & $1.1(1.0-1.5)$ & 0.71 \\
\hline \multicolumn{2}{|l|}{ Former } & 362 & $2.1(1.8-2.3)$ & 314 & $1.7(1.5-1.9)$ & 0.02 \\
\hline \multirow{2}{*}{\multicolumn{2}{|c|}{ Current }} & 154 & $3.0(2.6-3.5)$ & 215 & $2.1(1.8-2.5)$ & \multirow[t]{2}{*}{$<0.01$} \\
\hline & & & $<0.001$ & & $<0.001$ & \\
\hline \multicolumn{7}{|l|}{ Alcohol } \\
\hline Never & & 103 & $2.9(2.3-3.6)$ & 64 & $1.7(1.2-2.4)$ & $<0.01$ \\
\hline Occasionally & & 32 & $2.0(1.4-3.1)$ & 21 & $1.7(1.0-2.9)$ & 0.61 \\
\hline \multirow{2}{*}{\multicolumn{2}{|c|}{ Regularly }} & 425 & $2.1(1.9-2.3)$ & 561 & $1.7(1.6-1.9)$ & \multirow[t]{2}{*}{$<0.01$} \\
\hline & & & 0.03 & & 1.0 & \\
\hline \multicolumn{7}{|l|}{ Obesity $\ddagger$} \\
\hline Absent & & 463 & $2.1(1.9-2.3)$ & 539 & $1.5(1.4-1.7)$ & \multirow{3}{*}{$\begin{array}{c}<0.001 \\
0.72\end{array}$} \\
\hline \multirow[t]{2}{*}{ Present } & \multirow[t]{2}{*}{$\doteqdot$} & \multirow[t]{2}{*}{96} & $3.0(2.4-3.7)$ & \multirow[t]{2}{*}{106} & $2.8(2.3-3.4)$ & \\
\hline & & & $<0.01$ & & $<0.001$ & \\
\hline \multicolumn{7}{|l|}{ Diabetes } \\
\hline Absent & & 526 & $2.2(2.0-2.4)$ & 624 & $1.7(1.5-1.9)$ & \multirow{3}{*}{$\begin{array}{c}<0.001 \\
0.15\end{array}$} \\
\hline \multirow{2}{*}{ Present } & & \multirow[t]{2}{*}{34} & $3.6(2.5-5.1)$ & \multirow[t]{2}{*}{22} & $2.3(1.3-4.1)$ & \\
\hline & & & $<0.01$ & & 0.23 & \\
\hline
\end{tabular}

* $P$-values mentioned in this column are those of ANOVA comparing. e.g. never, former and current smokers.

tMedian values of $C$-reactive protein level showed the same trend.

†For two persons length and weight were not available.

for the second, third or fourth quintile compared to the first quintile.

\section{Discussion}

This study amongst 560 men with a first myocardial infarction and 646 control subjects shows that $C$ reactive protein levels are associated with myocardial infarction, with a nearly 2 -fold increased risk for persons in the highest quintile of $\mathrm{C}$-reactive protein levels, compared with those in the lowest quintile. Many major cardiovascular risk factors such as age, smoking, obesity and diabetes were associated with high C-reactive protein levels. Systolic blood pressure and triglyceride levels were positively associated with $\mathrm{C}$-reactive protein levels, and HDL cholesterol was negatively associated with $\mathrm{C}$-reactive protein levels. This implies that the relationship of C-reactive protein levels with myocardial infarction is confounded by these factors. Adjustment for cardiovascular risk factors, in particular, adjustment for total cholesterol, HDL cholesterol and triglycerides, substantially decreased the risk of myocardial infarction for men in the highest quintile to 1.3 (95\% CI: 0.9-1.9) compared to men in the lowest quintile. Thus, the association of $\mathrm{C}$-reactive protein levels with myocardial infarction can, to a large extent, be explained by the presence of cardiovascular risk factors.

C-reactive protein levels amongst patients were higher compared with control subjects, which corresponds to the results of the Physicians' Health Study (PHS) [11]. Both that study and this one show C-reactive protein as a predictor of myocardial infarction. In our study, most of the risk associated with $\mathrm{C}$-reactive protein disappeared after adjustment for other risk factors. This is corroborated by the Dutch Hoorn study, a 5-year follow-up study, in which the relative risk between $C$-reactive protein and cardiovascular mortality also substantially decreased after adjustment for several risk factors [17]. It is also corroborated by a Danish nested casecontrol study, in which C-reactive protein was not an independent predictor of coronary heart disease [18]. The most likely, though not only, explanation is that $\mathrm{C}$-reactive protein level predicts risk because 
Table 3 C-reactive protein levels by quintile of total cholesterol. HDL cholesterol and triglycerides amongst patients with myocardial infarction and control subjects

\begin{tabular}{|c|c|c|c|c|c|c|}
\hline \multirow[b]{3}{*}{ Quintile } & \multirow[b]{3}{*}{ Range } & \multicolumn{4}{|c|}{ C-reactive protein $\left(\mathrm{mg} \mathrm{L}^{-1}\right)$} & \multirow{3}{*}{$\begin{array}{l}P \text {-value of difference } \\
\text { patients and control } \\
\text { subjects }\end{array}$} \\
\hline & & \multicolumn{2}{|l|}{ Patients } & \multicolumn{2}{|c|}{ Control subjects } & \\
\hline & & Number + & Mean $(\mathrm{CI})^{* \dagger}$ & Number* & Mean $(\mathrm{CI})^{*} \dagger$ & \\
\hline \multicolumn{7}{|c|}{ Total cholesterol (mmol L $\left.{ }^{-1}\right)$} \\
\hline 1 & $<5.02$ & 85 & $2.3(1.7-3.0)$ & 128 & $1.8(1.4-2.3)$ & 0.20 \\
\hline 2 & $5.02-5.57$ & 112 & $2.2(1.8-2.7)$ & 129 & $1.5(1.2-1.8)$ & $<0.01$ \\
\hline 3 & $5.58-6.08$ & 104 & $2.1(1.7-2.6)$ & 129 & $1.6(1.3-2.0)$ & 0.06 \\
\hline 4 & $6.09-6.79$ & 129 & $2.1(1.7-2.5)$ & 128 & $1.8(1.5-2.2)$ & 0.34 \\
\hline 5 & $\geq 6.80$ & 126 & $\begin{array}{l}2.4(2.0-2.9) \\
0.84\end{array}$ & 131 & $\begin{array}{l}2.0(1.6-2.4) \\
0.26\end{array}$ & 0.11 \\
\hline \multicolumn{7}{|c|}{ HDL cholesterol ( $\left.\mathrm{mmol} \mathrm{L}^{-1}\right)$} \\
\hline 1 & $<1.06$ & 197 & $2.8(2.4-3.2)$ & 128 & $2.4(2.0-3.0)$ & 0.30 \\
\hline 2 & $1.06-1.22$ & 133 & $2.3(1.9-2.9)$ & 128 & $2.1(1.7-2.6)$ & 0.49 \\
\hline 3 & $1.23-1.38$ & 109 & $2.1(1.6-2.6)$ & 130 & $1.5(1.3-1.9)$ & 0.05 \\
\hline 4 & $1.39-1.61$ & 83 & $1.8(1.4-2.2)$ & 129 & $1.3(1.1-1.6)$ & 0.06 \\
\hline 5 & $\geq 1.62$ & 32 & $\begin{aligned} & 1.1(0.8-1.5) \\
< & 0.001\end{aligned}$ & 128 & $\begin{aligned} & 1.4(1.1-1.7) \\
< & 0.001\end{aligned}$ & 0.26 \\
\hline \multicolumn{7}{|c|}{ Triglycerides $\left(\mathrm{mmol} \mathrm{L}^{-1}\right)$} \\
\hline 1 & $<0.83$ & 42 & $2.1(1.4-3.2)$ & 125 & $1.4(1.1-1.7)$ & 0.07 \\
\hline 2 & 0.83-1.09 & 60 & $2.0(1.5-2.8)$ & 131 & $1.5(1.2-1.9)$ & 0.15 \\
\hline 3 & $1.10-1.41$ & 103 & $2.2(1.8-2.8)$ & 131 & $1.7(1.4-2.1)$ & 0.11 \\
\hline 4 & $1.42-2.03$ & 154 & $2.4(2.0-2.9)$ & 128 & $1.9(1.6-2.3)$ & 0.08 \\
\hline 5 & $\geq 2.04$ & 198 & $\begin{array}{l}2.2(1.9-2.5) \\
0.75\end{array}$ & 130 & $\begin{array}{l}2.1(1.8-2.5) \\
0.02\end{array}$ & 0.93 \\
\hline
\end{tabular}

*P-values mentioned in this column are those of ANOVA, comparing. e.g. C-reactive protein levels by quintiles of total cholesterol within patients.

$\dagger$ Median values of $C$-reactive protein level showed the same trend.

fCholesterol levels were missing for three patients and one control subject. HDL cholesterol levels for six patients and three control subjects and triglyceride levels for three patients and one control subject.

it is a marker for these other risk factors. In the MONICA Augsburg Cohort study, the relationship between $\mathrm{C}$-reactive protein levels and the incidence of coronary heart disease events also decreased after adjustments were made [19]. However, the effect in the PHS, after adjustment for several identical risk factors, remained [11]. In the analysis in which patients were matched with control subjects on the

Table 4 Risk of myocardial infarction with increasing quintile of C-reactive protein levels after adjustment for cardiovascular risk factors (odds ratios with $95 \%$ confidence interval)

\begin{tabular}{llllll}
\hline & & \multicolumn{5}{c}{ Quintile of C-reactive protein level $\left(\mathrm{mg} \mathrm{L}^{-1}\right)$} \\
\cline { 5 - 7 } Variable adjusted for & $<0.65$ & $0.65-1.18$ & $1.19-2.07$ & $2.08-4.23$ & $\geq 4.24$ \\
\hline- & 1 & $0.9(0.6-1.3)$ & $1.1(0.7-1.6)$ & $1.7(1.2-2.4)$ & $1.9(1.3-2.7)$ \\
Age & 1 & $0.8(0.6-1.2)$ & $1.0(0.7-1.5)$ & $1.6(1.1-2.2)$ & $1.8(1.2-2.6)$ \\
Age, smoking & 1 & $0.8(0.6-1.2)$ & $1.0(0.7-1.5)$ & $1.6(1.1-2.3)$ & $1.8(1.2-2.6)$ \\
$\begin{array}{l}\text { Age, smoking, diabetes, alcohol, obesity, systolic } \\
\quad \text { and diastolic blood pressure }\end{array}$ & 1 & $0.8(0.5-1.2)$ & $1.1(0.7-1.6)$ & $1.7(1.1-2.5)$ & $1.8(1.2-2.7)$ \\
$\begin{array}{l}\text { Age, total cholesterol, HDL cholesterol and } \\
\text { triglycerides }\end{array}$ & 1 & $0.8(0.5-1.2)$ & $0.8(0.6-1.3)$ & $1.2(0.8-1.8)$ & $1.3(0.9-1.9)$ \\
$\begin{array}{l}\text { Age, smoking, diabetes, alcohol, obesity, systolic } \\
\text { and diastolic blood pressure, total cholesterol. }\end{array}$ & 1 & $0.8(0.5-1.2)$ & $0.9(0.6-1.4)$ & $1.4(1.0-2.2)$ & $1.4(0.9-2.1)$ \\
HDL cholesterol and triglycerides & & & & & \\
\hline
\end{tabular}


presence or absence of subclinical disease, the Cardiovascular Health Study found a nonsignificant 1.8-fold increased risk of myocardial infarction for men in the highest quartile [12]. This is in contrast with the Multiple Risk Factor Intervention Trial. This latter study included only high risk men, which probably accounts for the similar baseline levels of C-reactive protein in patients with a myocardial infarction and control subjects [13].

The levels of $\mathrm{C}$-reactive protein differ between studies, which is likely to be the result of different prevalences of cardiovascular risk factors, such as smoking, obesity, diabetes and hypertension, which are associated with high C-reactive protein levels. It has been suggested that $\mathrm{C}$-reactive protein might causally affect atherosclerosis or thrombosis, and thereby increase the risk of myocardial infarction [ 1 . 5]. Reversely, cardiovascular risk factors promote atherosclerosis and the increase in C-reactive protein levels in patients with myocardial infarction could reflect the intrinsic inflammation and tissue damage within the arterial lesions. Another possibility in this respect might be prior infection with Helicobacter Pylori and Chlamydia Pneumoniae, which in some studies, but not all, are associated with coronary heart disease and various cardiovascular risk factors, and with increased production of $\mathrm{C}$ reactive protein levels [20-23]. We must also retain that $\mathcal{C}$-reactive protein levels might be a surrogate for cytokines. Recently, it has been suggested that Creactive protein might activate the complement system, thereby promoting inflammation and thrombosis [24]. C-reactive protein could also act as an intermediate factor in the association of cardiovascular risk factors and myocardial infarction. After adjustment for several cardiovascular risk factors, the risk of myocardial infarction for men in the highest quintile decreased to a nonsignificant 1.4-fold increased risk, supporting this option. Residual confounding, i.e. the presence of unknown confounders, could well explain the remaining $40 \%$ increased risk.

We found that increasing age was associated with increasing C-reactive protein levels. These results are in agreement with a study amongst 303 men aged 50-69 years from London. in which increased levels were found with increasing age [21]. This is to be expected, as cardiovascular risk factors are likely to accumulate in the elderly. As C-reactive protein levels are elevated in the presence of these risk factors, higher levels are found in older people. This could also explain why the difference in C-reactive protein levels between patients and control subjects diminishes with increasing age; control subjects probably catch up with patients with regard to the presence of cardiovascular risk factors. In the Cardiovascular Health Study amongst adults aged 65 years and older, no association between age and levels of C-reactive protein was found [25]. Another explanation for the increase in C-reactive protein levels with increasing age, is the increase in prevalence of inflammatory disorders in the elderly.

Amongst patients and healthy control subjects, a clear association existed between smoking and $\mathrm{C}$ reactive protein levels, with smokers having the highest level, which confirms the results of other studies $[8,11,17-19,26]$. This agrees wit the concept that smoking causes bronchial infla hmation, as C-reactive protein is a marker of infla hamation and thus an elevation in levels was to be expected. We found a strong association between obesity and C-reactive protein levels, which confirms the results of other studies [17-19, 21, 25-27]. It is hypothesized that adipose tissue may play a role in the regulation of serum $C$-reactive protein levels via interleukin-6 production [27]. A positive and negative association with, respectively, triglycerides and HDL cholesterol, without any association of Creactive protein levels with total cholesterol in control subjects, has also been reported before [21, 25].

Several points need to be made with regard to our 'Study of Myocardial Infarctions Leiden'. Our results only apply to men, as we did not include women. In several studies in which women were included the results were more pronounced than amongst men $[12,28]$. However, amongst women the risk of cardiovascular events also decreased substantially after adjustment for several risk factors, as in our study [29]. C-reactive protein was no longer an independent predictor of coronary heart disease in a follow-up study including both men and women [18]. As C-reactive protein levels are measured at least 6 months after the myocardial infarction, and for most patients several years later, we cannot be certain that they reflect the pre-myocardial infarction levels. Levels could have become elevated as a consequence of myocardial infarction. Moreover, our study only included individuals who had survived a myocardial infarction. A study amongst 
188 patients with a myocardial infarction described that patients dying within 6 months had a high rise in $\mathrm{C}$-reactive protein measured several hours after the onset of symptoms [30]. Since we saw no effect of time since the event, at least 6 months later. neither is likely to have affected our results. If there were a persistent effect as a result of the event, it would increase the difference between patients and controls and could not explain the absence of a significant effect in the adjusted analysis. As a control group, we invited persons who had undergone an orthopaedic intervention more than 6 months ago, the majority of whom had the intervention more than 2 years previously. It is very unlikely that an intervention so long ago influenced $\mathrm{C}$-reactive protein levels, especially since most interventions were connected with a passing injury. Both control subjects and patients were living in the same area, and so we believe that our control group is a good representation of the general population from where the patients arose.

In conclusion, C-reactive protein levels are higher amongst patients with a previous myocardial infarction compared with controls, and an increased risk of myocardial infarction seems apparent with increasing quintile of C-reactive protein. As the level of C-reactive protein is associated with several cardiovascular risk factors, the risk of myocardial infarction diminished after adjustment for these risk factors and resulted in a nonsignificant 1.4-fold increased risk for men in the highest quintile. compared to men in the lowest quintile. Adjustment for lipids in particular, decreased the risk to 1.3 -fold. Therefore, the association of $\mathrm{C}$-reactive protein levels with risk of myocardial infarction is largely explained by other risk factors, and the remaining unconfounded association, if it exists, is small.

\section{Acknowledgements}

The authors wish to thank the cardiologists of the departments of cardiology, Leiden University Medical Center and the general hospital Diaconessenhuis Leiden and Dr F.J.M. van der Meer. head Leiden Anticoagulant Clinic, for their kind cooperation, and Dr J.H.M. Souverijn for his assistance with the lipid measurements. We thank Mrs T. Visser for drawing blood samples and Mrs A. Böing, Mrs M.C.L. Schaap and Mr F.P.H.T.M. Romijn for performing the laboratory measurements. Mrs J.J. Schreijer is thanked for her secretarial and administrative support. We also express our gratitude to all individuals who participated in the 'Study of Myocardial Infarctions Leiden'. This research was supported by the Netherlands Heart Foundation (Grant no. 92.345).

\section{References}

1 Ross R. The pathogenesis of atherosclerosis: a perspective for the 1990s. Nature 1993: 362: 801-9.

2 Munro JM. Cotran RS. The pathogenesis of atherosclerosis: atherogenesis and inflammation. Lab mest 1988: 58: 24961.

3 Alexander RW. Inflammation and coronary artery disease. N Engl J Med 1994: 331: 468-9.

4 Cermak J. Key NS. Bach RR. Balla J. Jacob HS. Vercellotti GM. C-reactive protein induces human peripheral blood monocytes to synthesize tissue factor. Blood 1993: 82: $513-$ 20.

5 Nieminen MS. Mattila K. Valtonen V. Infection and inflammation as risk factors for myocardial infarction. Eur Heart J 1993: 14 (Suppl. K): 12-6.

6 Pepys MB. Weatherall DJ. Ledingham JGG. Warrell DA, eds. The acute phase response and C-reactive protein. In: Oxford Textbook of Medicine 3. Oxford: Oxford University Press. 1996: 1527-33.

7 Berk BC. Weintraub WS. Alexander RW. Elevation of Creactive protein in 'active' coronary artery disease. Am J Cardiol 1990; 65: 168-72.

8 Haverkate F. Thompson SG. Pyke SDM. Gallimore JR. Pepys MB. Production of C-reactive protein and risk of coronary events in stable and unstable angina. Lmcet 1997: 349: $462-6$.

9 Toss H. Lindahl B. Siegbahn A. Wallentin L. Prognostic influence of increased fibrinogen and C-reactive protein levels in unstable coronary artery disease. Circulation 1997: 96: 4204-10.

10 Biasucci LM. Liuzzo G. Grillo RL. Caligiuri G. Rebuzzi AG. Buffon A et al. Elevated levels of C-reactive protein at discharge in patients with unstable angina predict recurrent instability. Circulation 1999: 99: 855-60.

11 Ridker PM. Cushman M. Stampfer MJ. Tracy RP. Hennekens CH. Inflammation, aspirin. and the risk of cardiovascular disease in apparently healthy men. $N$ Engl ) Med 1997: 336: 973-9.

12 Tracy RP. Lemaitre RN. Psaty BM. Ives DG. Evans RW. Cushman $M$ et al. Relationship of C-reactive protein to risk of cardiovascular disease in the elderly. Results from the Cardiovascular Health Study and the Rural Health Promotion Project. Arterioscler Thromb Vasc Biol 1997: 17: 11217.

13 Kuller LH. Tracy RP. Shaten J. Meilahn EN. Relation of Creactive protein and coronary heart disease in the MRFIT nested case-control study. Am J Epidemiol 1996: 144: 53747.

14 Doggen CJM. Manger Cats V. Bertina RM. Rosendaal FR. Interaction of coagulation defects and cardiovascular risk factors: increased risk of myocardial infarction associated with factor V Leiden or prothrombin 20210A. Circulation 
1998: 97: 1037-41.

15 Woolf B. On estimating the relation between blood group and disease. Amn Hum Gentet 1955: 19: 251-3.

16 Schlesselman IJ. Schlesselman JJ. eds. Basic methods of analysis. In: Case-Control Studies. New York. Oxford: Oxford University Press. 1982: 203-6.

17 Jager A. Hinsbergh VWM. Kostense PJ. Emeis JJ. Yudkin JS. Nijpels $G$ et al. Von Willebrand factor. C-reactive protein. and 5-year mortality in diabetic and nondiabetic subjects. The Hoorn Study. Arterioscler Thromb V'asc Biol 1999: 19: $3071-8$.

18 Gram I. Bladbjerg EM. Moller L. Sjol A. Jespersen I. Tissuetype plasminogen activator and C-reactive protein in acute coronary heart disease. A nested case-control study. I intern Med 2000 247: 205-12.

19 Koenig W. Sund M. Fröhlich M. Fischer H. Löwel H. Döring A et al. C-reactive protein. a sensitive marker of inflammation. predicts future risk of coronary heart disease in intially healthy middle-aged men. Results from the MONICA (Monitoring Trends and Determinants in Cardiovascular Disease) Augsburg Cohort Study. 1984-92. Circulation 1999: 99: $23 \bar{\top}-42$.

20) Patel P. Mendall MA. Carrington D. Strachan DP. Leatham E. Molineaux $\mathrm{N}$ ot al. Association of Helicobucter pylori and Chlumudia pueumonime infections with coronary heart disease and cardiovascular risk factors. Br Med J 1995: $311: 711-4$.

21 Mendall MA. Patel P. Ballam L. Strachan D. Northfield TC. C reactive protein and its relation to cardiovascular risk (actors: a population based cross sectional study. $\mathrm{Br}$. Wed I 1996: 312: 1061-5.

22 Ridker PM. Kundsin RB. Stampfer MJ. Poulin S. Hennekens $\mathrm{CH}$. Prospective study of Chlimydia pmeumonine IgG seropositivity and risks of future myocardial infarction. Circulation 1999: 99: 116l-4

23 Parente F. Imbesi V. Cucino C. Maconi G. Russo U. Duca PG. Bianchi Porro G. Helicobacter pylori CagA seropositivity does not inlluence inflammatory parameters. lipid concentrations and haemostatic factors in healthy individuals. I Intern .Med 2000: $24 \pi: 213-7$.
24 Lagrand WK. Visser CA. Hermens WT. Niessen HWM Verheugt FWA. Wolbink G. Hack E. C-reactive protein as a cardiovascular risk factor. More than an epiphenomenon? Circulation 1999: 100: 96-102

25 Tracy RP. Psaty BM. Macy E. Bovill EG. Cushman M. Cornel ES, Kuller LH. Lifetime smoking exposure affects the association of $\mathrm{C}$-reactive protein with cardiovascular disease risk factors and subclinical disease in healthy elderly subjects. Arterioscler Tirromb Vasc Biol 1997: 17: 2167-76.

26 Danesh J. Muir J. Wong Y. Ward M. Gallimore JR. Pepys MB Risk factors for coronary heart disease and acute-phase proteins. Eur Heart / 1999: 20: 954-9.

27 Yudkin JS. Stehouwer CD. Eme1s JI. Coppack SW. C-reactive protein in healthy subjects: associations with obesity. insulin resistance. and endothelial dysfunction: a potential role for cytokines originating from adipose tissue? Arterioscler Thromb Vasc Biol 1999: 19; 972-8.

28 Ridker PM. Buring J. Shih J. Matias M. Henneken $\mathrm{CH}$. Prospective study of C-reactive protein and the risk of the cardiovascular events among apparently healthy wimen. Circulation 1998; 98: 331-3.

29 Ridker PM. Hennekens CH. Buring JE. Rifai N. C-reactive protein and other markers of inflammation in the prediction of cardiovascular disease in women. $N$ Engl J Med 2000342 : $836-43$.

30 Pietilä KO. Harmoinen AP. Jokiniitty J. Pasternack AI Serum $C$-reactive protein concentration in acute myocardial infarction and its relationship to mortality during 24 months of follow-up in patients under thrombolytic treatment. Eur Heart J 1996: 17: 1345-9.

Received 26 May 2000: revision received 8 August 2000: accepted 10 August 2000 .

Correspondence: Professor Dr F. R. Rasendaal. Department of Clinical Epidemiology. Building 1 CO-P, Leiden University Medical Center, PO Box 9600.2300 RC Leiden, the Netherlands (fax: +31 71 5248122: e-mail: F.R.Rosendaal@lumc.nl). 